American Journal of Applied Sciences 6 (4): 772-783, 2009

ISSN 1546-9239

(C) 2009 Science Publications

\title{
Assessment of Groundwater and Surface Water Pollution at Mitm Area, Ibb City, Yemen
}

\author{
${ }^{1}$ Esmail Al Sabahi, ${ }^{1}$ Abdul Rahim S., ${ }^{1}$ Wan Zuhairi W.Y., ${ }^{1}$ Fares Alshaebi and ${ }^{2}$ Fadhl Al Nozaily \\ ${ }^{1}$ Geology Program, School of Environment and Natural Resource Sciences, Faculty of Science and \\ Technology, University Kebangsaan Malaysia, 43600 Bangi Selangor, Malaysia \\ ${ }^{2}$ Water and Environment Center, Sana'a University, Republic of Yemen
}

\begin{abstract}
Groundwater and surface water samples were collected from Mitm area to study the possible impact of wastewater treatment percolation into the groundwater and surface water. The objective of the study is to assess the groundwater and surface water pollution due to wastewater treatment at Mitm area of Ibb city, in the Republic of Yemen. The concentrations of various physiochemical parameters include heavy metals $(\mathrm{Pb}, \mathrm{Zn}, \mathrm{Ni}, \mathrm{Cr}, \mathrm{Cd}, \mathrm{Cu}) \mathrm{pH}$, temperature, Electrical Conductivity (EC), Total Dissolved Solids (TDS), and Dissolved Oxygen (DO), anions and nutrients $\left(\mathrm{F}^{-}, \mathrm{Cl}^{-}, \mathrm{SO}_{4}^{-2}, \mathrm{NO}_{2}, \mathrm{NO}_{3}{ }^{-}, \mathrm{NH}_{3}-\mathrm{N}\right)$, major cations $(\mathrm{Fe}, \mathrm{Na}, \mathrm{K}, \mathrm{Ca}, \mathrm{Mg})$ and parameters $\left(\mathrm{COD}, \mathrm{BOD}_{5}\right.$, and coliform group bacteria) were measured from the groundwater samples. The results show that three out of five boreholes are contaminated, where the concentration of physic-chemical parameters are above the standard acceptable levels which required for drinking water adapted by Yemen's Ministry of Water and Environment (YMWE, 1999). On the other hand, surface water is affected by the discharge of untreated wastewater. The concentrations of physiochemical parameters are above the standard acceptable levels which required for irrigation purpose adopted by Yemen's Ministry of Water and Environment (YMWE, 1999). Boreholes 1 and 2 are suitable for drinking water, whereas boreholes 3, 4 and 5 are not suitable for drinking water. Therefore, urgency for wastewater treatment at this site is recommended to prevent further contamination to surface and groundwater.
\end{abstract}

Key words: Surface water, groundwater, pollution, heavy metals

\section{INTRODUCTION}

Pollution occurs when a product added to our natural environment adversely affects nature's ability to dispose it off. A pollutant is something which adversely interferes with health, comfort, property or environment of the people. Generally, most pollutants are introduced in the environment as sewage, waste, accidental discharge and as compounds used to protect plants and animals. There are many types of pollution such as air pollution, soil pollution, water pollution, nuclear pollution and oil pollution ${ }^{[10]}$.

In developing countries only a small proportion of the wastewater produced by sewered communities is treated. Developing country governments and their regulatory agencies, as well as local authorities (which may be city or town councils, or specific wastewater treatment authorities, or more generally water and sewerage authorities ), need to understand that domestic and other wastewaters require treatment before discharge or, preferably, re-use in agriculture and/or aquaculture $^{[6]}$.

Many countries have included wastewater reuse as an important dimension of water resources planning. In the more arid areas of Australia and the USA wastewater is used in agriculture, releasing high quality water supplies for potable use. Some countries, for example the Hashemite Kingdom of Jordan and the Kingdom of Saudi Arabia, have a national policy to reuse all treated wastewater effluents and have already made considerable progress towards this end ${ }^{[15]}$

Municipal wastewater effluents may contain a number of toxic elements, including heavy metals, because under practical conditions wastes from many small and informal industrial sites are directly discharged into the common sewer system. These toxic elements are normally present in small amounts and, hence, they are called trace elements. Some of them may be removed during the treatment process but others will persist and could present phytotoxic problems.

Corresponding Author: Esmail Al Sabahi, ${ }^{1}$ Geology Program, School of Environment and Natural Resource Sciences, Faculty of Science and Technology, University Kebangsaan Malaysia, 43600 Bangi Selangor, Malaysia 
Am. J. of Appl. Sci., 6 (4): 772-783, 2009

Thus, municipal wastewater effluents should be checked for trace element toxicity hazards, particularly when trace element contamination is suspected ${ }^{[13]}$.

Groundwater is that portion of subsurface water which occupies the part of the ground that is fully saturated and flows into a hole under pressure greater than atmospheric pressure. Groundwater occurs in geological formations known as aquifer. An aquifer (gravel/ sand) may be defined as a geologic formation that contains sufficient permeable materials to yield significant quantities of water to wells and springs; this implies an ability to store and transmit water ${ }^{[4]}$.

Groundwater is an important source of drinking water for humankind. It contains over $90 \%$ of the fresh water resources and is an important reserve of good quality water. Groundwater, like any other water resource, is not just of public health and economic value; it also has an important ecological function ${ }^{[3]}$.

Wastewater treatment plant of Ibb city was established for receiving $5000 \mathrm{~m}^{3}$ per day, but now it receives more than $15000 \mathrm{~m}^{3}$ per day. Untreated wastewater is going directly to the valley of Mitm area in which will cause the environmental pollution.

\section{MATERIAL AND METHODS}

Ibb city (Fig. 1) is located between Sana'a, the capital of Yemen, and Taiz governorates. Ibb city is located at latitude $13^{\circ} 58^{\prime} 48^{\prime \prime}$ and longitude $44^{\circ} 10^{\prime} 48^{\prime \prime}$. Ibb is situated in a fault controlled valley close to the main watershed of the Wadi Zabid at an elevation of about $2000 \mathrm{~m}$ above sea level.

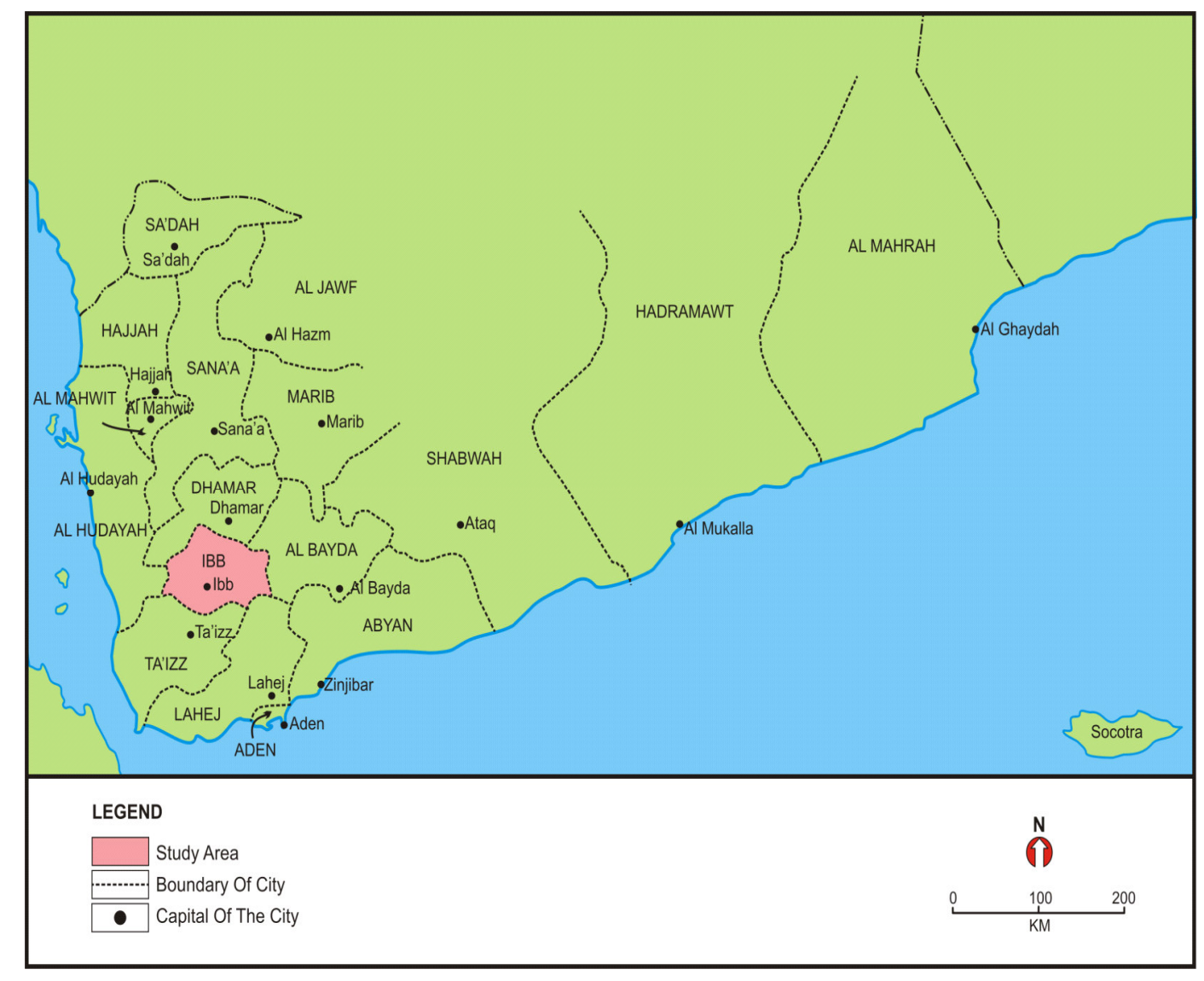

Fig. 1: Location of Ibb city

Figure 1 location of Ibb cityGroundwater samples were collected from five boreholes. Two of these boreholes are located before wastewater treatment plant, whereas the other three boreholes are located after wastewater treatment pant. Surface water samples were also collected from three different sites, the upstream, the middle, and the downstream of Mitm valley (Fig. 2). Glass and polyethylene bottles were used to collect groundwater samples. Water samples preserved for $\mathrm{BOD}_{5}$ and $\mathrm{COD}$ tests were collected in polyethylene 


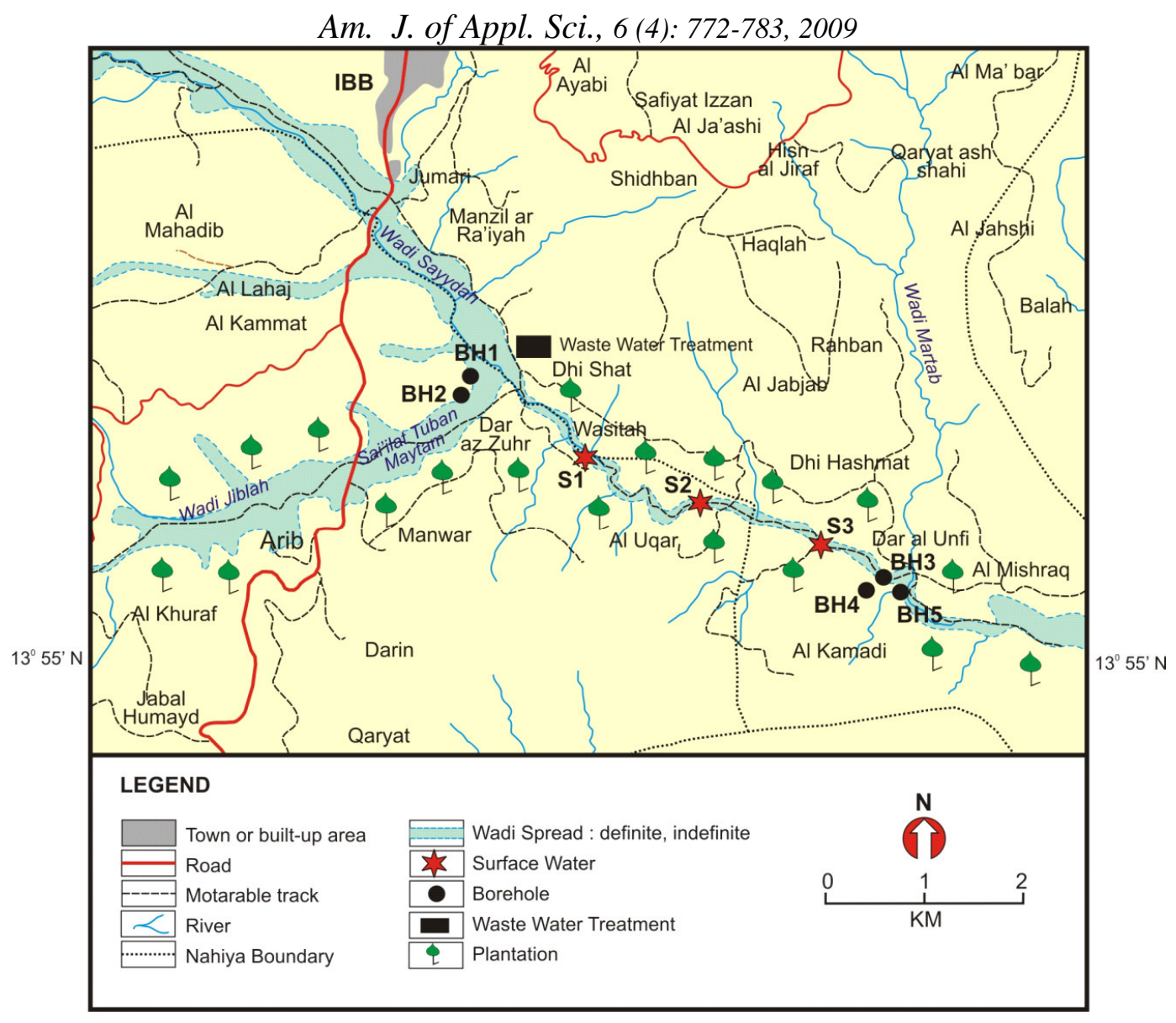

Fig. 2: Locations of groundwater and surface water samples

bottles covered with aluminum foils. A few drops of concentrated nitric acid were added to all the water samples collected for heavy metals analysis to make the $\mathrm{pH}$ equal 2.0. The samples were then transported in a cool box to be stored under suitable temperature until analysis.

The laboratory of Ibb Water and Sanitation Local Corporation (IWSLC) was used for analyzing the water samples. Spectrophotometer HACH (DR 4000 models 48000 and 48100) was used for measuring of $\mathrm{PO}_{4}, \mathrm{SO}_{4}$, $\mathrm{NO}_{3}, \mathrm{NO}_{2}, \mathrm{~F}$, and $\mathrm{NH}_{3}$. BOD Trak HACH was used for determining the $\mathrm{BOD}_{5}$. Flame photometer (PFP 7) was used to determine Sodium (Na) and Potassium (K). The Yemen Standardization Meterology and Water Quality control Organization in Sana'a were used for preparing and analyzing the heavy metals via Inductively Coupled Plasma of Optical Emission Spectrometry (ICP-OES) model Vista MPX.

Chloride was measured by the Mercuric Nitrate Titrimetric Method. $25 \mathrm{~mL}$ of water samples was placed in Erlenmeyer flask, and then Diphenylcarbazone regent was added to the sample. The solution was bluegreen, when Mercuric Nitrate was added as a titrant, the color of solution changed from blue-green to purple, making the end point of the titrant.

Calcium was measured by the EDTA titrimetric methods which involves the use of solutions of ethylene di amin titra acetic acid. $25 \mathrm{ml}$ of water sample was placed in a conical flask, and then $2 \mathrm{~mL}$ of buffer solution was added to the sample. Man Ver 2 Calcium indicator was also added to the sample. The solution was wine red, when EDTA was added as a titrant, the color of solution changed from wine red to blue, making the end point of the titrant.

The hardness was measured by the EDTA titrimetric methods which involves the use of solutions of ethylene di amin titra acetic acid. $25 \mathrm{~mL}$ of water sample was placed in a conical flask, and then $2 \mathrm{~mL}$ of buffer solution was added to the sample. Man Ver 2 Hardness indicator was also added to the sample. The solution was wine red, when EDTA was added as a titrant, the color of solution changed from wine red to blue, making the end point of the titrant. 
Am. J. of Appl. Sci., 6 (4): 772-783, 2009

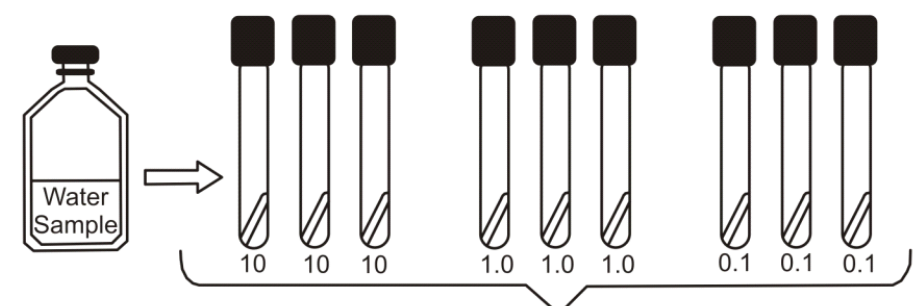

A
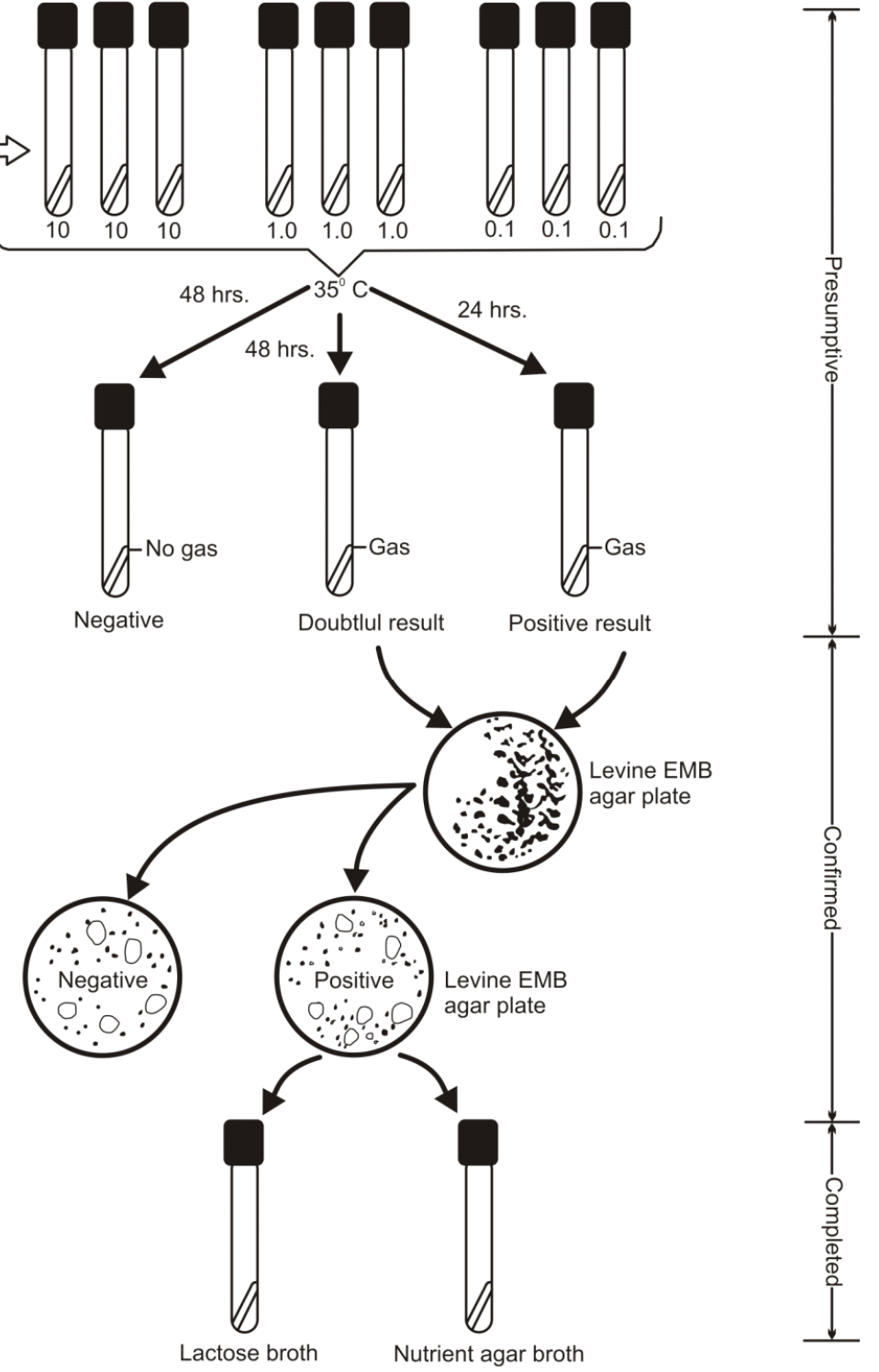

Fig. 3: Bacteriological analysis of water for coliform bacteria

Magnesium was measured by calculation as the difference between total hardness and calcium hardness as follows:

Total hardness $\left(\right.$ as $\left.\mathrm{CaCO}_{3}\right)=2.497\left[\mathrm{Ca}^{2+}, \mathrm{mg} \mathrm{L}^{-1}\right]+$ $4.118\left[\mathrm{Mg}^{2+}, \mathrm{mg} \mathrm{L}^{-1}\right]$.

Then

$4.118\left[\mathrm{Mg}^{2+}, \mathrm{mg} \mathrm{L}^{-1}\right]=$ Total hardness (as $\left.\mathrm{CaCO} 3\right)$ $2.497\left[\mathrm{Ca}^{2+}, \mathrm{mg} \mathrm{L}^{-1}\right]$

Where

Ca hardness $=\mathrm{Ca}$ ion $\times 2.5$

$\mathrm{Mg}$ hardness $=\mathrm{Mg}$ ion $\times 4.11$
Microbiological analysis: Nine tubes of lactose broth (Fig. 3) were prepared according to the size of the water sample i.e. $0.1 \mathrm{~mL}, 1 \mathrm{~mL}$, and $10 \mathrm{~mL}$ respectively for all water samples. The test tubes are placed in incubator at $35^{\circ} \mathrm{C}$ for 24 hours for gas production. Table 3 shows the Most Probable Number (MPN) of coliforms. Production of gas confirms the presence of coliform in the sample. To confirm the presence of coliform, Eosin Methylen Blue agar (EMB) was used in which contains methylene blue that inhibits coliforms. The plates of Eosin Methylen Blue agar (EMB) is placed in incubator 
Am. J. of Appl. Sci., 6 (4): 772-783, 2009

after streaking at $35^{\circ} \mathrm{C}$ for $24 \mathrm{~h}$. E.coli colonies on this medium are small with metallic sheen. A single colony from EMB agar plate was picked up and inoculated it into lactose broth. The lactose broth was showed a cid and gas production confirms the presence of coliform bacteria.

\section{RESULTS AND DISCUSIONS}

Insitu parameters: The results of the measured insitu parameters including $\mathrm{pH}$, Temperature $(\mathrm{T})$, Electrical Conductivity (EC), Total Dissolved Solids (TDS) and Dissolved Oxygen (DO) are shown in Table 1.

The $\mathrm{pH}$ values of all boreholes are shown in Table 1. The highest value of 7.7 is measured in BH5, whereas the lowest value of 7.3 is measured in BH4. The $\mathrm{pH}$ values are close to the results (7.6) obtained by Header et al. ${ }^{[9]}$. These results are also in agreement with the range values set by Yemen's Ministry of Water and Environment ${ }^{[17,15]}$. On the other hand, the $\mathrm{pH}$ values of all surface water are also shown in Table 1 . The highest value of 8.0 is measured at the downstream site, whereas the lowest value of 7.3 is measured at the upstream site. $\mathrm{pH}$ usually has no direct impact on consumers. It is one of the most important operational water quality parameters. If the $\mathrm{pH}$ is above 7 , this will indicate that water is probably hard and contains calcium and magnesium ${ }^{[5]}$. The normal $\mathrm{pH}$ range for irrigation water is from 6.5-8.4. $\mathrm{pH}$ values outside this range are a good warning that the water is abnormal in quality ${ }^{[13]}$. This means that, $\mathrm{pH}$ values for boreholes and surface water are in the normal values for drinking water and for irrigation purpose.

The temperature measurements between boreholes are very close. The highest value is measured in $\mathrm{BH} 2$ $\left(24.0^{\circ} \mathrm{C}\right)$, whereas, the lowest values in $\mathrm{BH} 4\left(21.6^{\circ}\right.$

C). These results are in agreement with the range values set by Yemen's Ministry of Water and Environment ${ }^{[14,15]}$. For the surface water, the highest value is measured at the downstream site, whereas, the lowest value is at the upstream site. Surface waters are, of course, subject to the effect of ambient temperatures and can be very warm during summer. The temperature of water affects the efficiency of treatment units. For example, in cold temperatures, the viscosity increases. This, in turn, diminishes the efficiency of settling of the solids that the water may contain because of the resistance that the high viscosity offers to the downward motion of the particles as they settle. Pressure drops also increase in the operation of filtration units, again, because of the resistance that the higher viscosity offers ${ }^{[2]}$.

Electrical Conductivity (EC) values show very different results between the boreholes. The highest value is recorded in BH4 $(1544.17 \mu \mathrm{S} / \mathrm{cm})$, whereas the lowest value is recorded in $\mathrm{BH} 2(639 \mu \mathrm{S} / \mathrm{cm})$. The high values of $\mathrm{EC}$ in $\mathrm{BH} 3, \mathrm{BH} 4$, and $\mathrm{BH} 5$ are not within the range values of $450-1000 \mu \mathrm{S} / \mathrm{cm}$ determined by Yemen's Ministry of Water and Environment ${ }^{[14,15]}$ which required for drinking water. On the other hand, $\mathrm{EC}$ values in $\mathrm{BH} 1$ and $\mathrm{BH} 2$ are within the Yemen standard value which is required for drinking water and this means that these two boreholes are not affected by the effluent of wastewater treatment plant. The high values of $\mathrm{EC}$ in $\mathrm{BH} 3, \mathrm{BH} 4$, and $\mathrm{BH} 5$ can be related to the effect of surface water seepage towards these boreholes.

Electrical Conductively (EC) values show variety results between three surface waters. The highest value is obtained at the upstream site with the value of $2646.65 \mu \mathrm{S} / \mathrm{cm}$, whereas the lowest value is obtained at the downstream site with the value of $2585 \mu \mathrm{S} / \mathrm{cm}$.

Table1: Insitu Parameters in Mitm area

\begin{tabular}{lllllr}
\hline Parameter & $\mathrm{pH}$ & $\mathrm{T}$ & $\mathrm{EC}(\mu \mathrm{S} / \mathrm{cm})$ & $\mathrm{DO}\left(\mathrm{mg}^{-1}\right)$ & $\left.\mathrm{TDS}^{-1} \mathrm{mg}^{-1}\right)$ \\
\hline Surface water 1 & 7.93 & 23.14 & 2646.65 & 1.10 & 1720.000 \\
Surface water 2 & 7.97 & 23.49 & 2610.00 & 1.15 & 1696.500 \\
Surface water 3 & 8.00 & 23.80 & 2585.00 & 1.20 & 1680.250 \\
BH1 & 7.58 & 23.00 & 736.00 & 3.10 & 478.400 \\
BH2 & 7.65 & 24.00 & 639.00 & 3.20 & 415.350 \\
BH3 & 7.70 & 22.77 & 1461.33 & 0.80 & 949.865 \\
BH4 & 7.30 & 21.60 & 1544.17 & 0.70 & 1003.710 \\
BH5 & 7.68 & 22.73 & 1365.83 & 0.60 & 887.790 \\
YMWE ${ }^{[17]}$ & $6.5-9$ & 25.00 & $450-1000$ & - & 1500.000 \\
WHO ${ }^{15]}$ & $6.5-9.5$ & - & - & - & 1200.000 \\
\hline
\end{tabular}

These results are high compared to the standard acceptable levels of drinking water and irrigation purpose determined by Yemen's Ministry of Water and Environment ${ }^{[14,15]}$ Conductivity was used to give an Table 2: The composition of wastewater at Ibb treatment plant idea of the amount of dissolved chemicals in water, and presence of $\mathrm{Na}, \mathrm{K}$, and $\mathrm{Cl}$. The elevated values of $\mathrm{EC}$ in the first three boreholes suggested that there is inorganic pollution compared to the last two boreholes. 
Am. J. of Appl. Sci., 6 (4): 772-783, 2009

\begin{tabular}{llllllll}
\hline Parameters & $\mathrm{pH}$ & $\mathrm{T}$ & $\mathrm{EC}(\mu \mathrm{S} / \mathrm{cm})$ & $\mathrm{DO} \mathrm{mg}$ & $\mathrm{TDS} \mathrm{mg}$ & $\mathrm{BOD}_{5}\left(\mathrm{mg}^{-1}\right)$ & $\mathrm{COD}\left(\mathrm{mg}^{-1}\right)$ \\
\hline Reading & 7.6 & 24 & 3050 & 1.2 & 1982.5 & 1420 & 1820 \\
\hline
\end{tabular}

Table 3: Water Quality Dissolved Oxygen $\left(\mathrm{mg}^{-1}\right)$

\begin{tabular}{ll}
\hline Good & Above 8.0 \\
\hline Slightly polluted & $6.5-8.0$ \\
Moderately polluted & $4.5-6.5$ \\
Heavily polluted & $4.0-4.5$ \\
Severely polluted & 4.0 \\
\hline
\end{tabular}

Table 4: $\mathrm{BOD}_{5}$ and COD at Mitm valley

\begin{tabular}{lrl}
\hline Parameters & BOD $_{5}$ & COD \\
\hline Surface water 1 & 728.4 & 982.40 \\
Surface water 2 & 723.2 & 970.67 \\
Surface water3 & 721.8 & 959.55 \\
YMWE, ${ }^{[1]}{ }^{17}{ }_{\text {Saudi Arabia, }}{ }^{14]}$ & 150.0 & 500.00 \\
Oman $^{[12]}{ }^{\left[{ }^{[8]}\right.}$ & 40.0 & 150.00 \\
Jordanian & 15.0 & 150.00 \\
\hline
\end{tabular}

Conductivity is not a problem in itself and just because it is above certain level does not mean that the water will cause illness ${ }^{[5]}$. In general, surface water is affected by untreated wastewater which discharges directly into the stream. Table 2 shows the composition of wastewater at Ibb wastewater treatment plant.

The Dissolved Oxygen (DO) values of the surface water show approximately different values. Oxygen becomes dissolved in surface waters by diffusion from the atmosphere and from aquatic-plant photosynthesis. Dissolved oxygen is consumed by the degradation (oxidation) of organic matter in water. Because the concentration of dissolved oxygen is never very large, oxygen-depleting processes can rapidly reduce it to near zero in the absence of efficient aeration mechanisms. Table 3 shows the water quality dissolved oxygen. This means that all surface waters are severely polluted.

Dissolved Oxygen (DO) measurements are varied. The highest concentration of $3.2 \mathrm{mg}^{-1}$ is measured in $\mathrm{BH} 2$, whereas the lowest concentration of $0.6 \mathrm{mg}^{-1}$ is measured in BH5. The lowest concentration of DO in $\mathrm{BH} 3, \mathrm{BH} 4$, and $\mathrm{BH} 5$ indicates that the effect of these boreholes by the migration of polluted surface water from the body of valley, and also indicates that these boreholes are rich with organic matter where bacteria used the oxygen to biodegrade it. It has been assumed that these pollutants are transported from polluted surface water and most likely will be transported to the groundwater and pollute it.

The concentrations of total dissolved solids (TDS) are different between the three surface waters. The highest value of $1720 \mathrm{mg}^{-1}$ is measured at the upstream Table 5: Concentration of major anions and nitrogenous compounds site, whereas the lowest value of $1682 \mathrm{mg}^{-1}$ is measured at the downstream site. These results are higher than the Jordanian standard ${ }^{[8]}$ and Oman standard $^{[12]}$ On the other hand these results are in agreement with the range values $\left(450-3000 \mathrm{mg}^{-1}\right)$ set by Yemen's Ministry of Water and Environment ${ }^{[13,14,15]}$ and Saudi Arabia standard which required for irrigation purpose.

The concentrations of Total Dissolved Solids (TDS) are also different between boreholes. The highest value of $1003.71 \mathrm{mg}^{-1}$ is measured in $\mathrm{BH} 4$, whereas, the lowest value of $415.35 \mathrm{mg}^{-1}$ is measured in $\mathrm{BH} 2$. The high concentrations of TDS in $\mathrm{BH} 3, \mathrm{BH} 4$, and BH5 can be attributed to the affect of these boreholes by polluted surface water. On the contrary, the low concentrations of TDS in $\mathrm{BH} 1$ and $\mathrm{BH} 2$ mean that these two boreholes did not affect these two boreholes by polluted surface water. Although the concentrations of TDS in $\mathrm{BH} 3, \mathrm{BH} 4$, and $\mathrm{BH} 5$ are high, these concentrations are within the standard acceptable levels of drinking water determined by Yemen's Ministry of Water and Environment ${ }^{[13,14,15]}$.

The concentration of $\mathrm{BOD}_{5}$ did not show different values between three surface waters (Table 4 ). The greatest concentration of $728.4 \mathrm{mg}^{-1}$ is measured at the upstream site, whereas the lowest concentration of $721.8 \mathrm{mg}^{-1}$ is measured at the downstream site. These results are not within the standard acceptable levels of irrigation purpose determined by Yemen's Ministry of Water and Environment ${ }^{[14,15]}$. On the other hand, these results are higher than the Saudi Arabia standard ${ }^{[14]}$, Oman standard ${ }^{[12]}$ and Jordanian standard ${ }^{[8]}$. The BOD $_{5}$ of sewage varies from several hundred to about 1000 $\mathrm{mg}^{-1}$ for raw sewage, and from about 10 to $20 \mathrm{mg}^{-1}$ for good quality secondary effluent ${ }^{[13]}$. This means that, the fresh wastewater is going directly to the valley and polluted the surface water body.

The COD values of the three surface waters showed different values. The highest value of 982.4 $\mathrm{mg}^{-1}$ is measured at the upstream site, whereas, the lowest value of $959.55 \mathrm{mg}^{-1}$ is measured at the downstream site. These results are also not within the standard acceptable levels of irrigation purpose determined by Yemen's Ministry of Water and Environment $^{[14,15]}$. On the other hand, these results are higher than the Saudi Arabia standard ${ }^{[14]}$, Oman standard $^{[12]}$ and Jordanian standard ${ }^{[8]}$. 


\begin{tabular}{|c|c|c|c|c|c|c|}
\hline \multicolumn{7}{|c|}{ Am. J. of Appl. Sci., 6 (4): 772-783, 2009} \\
\hline Surface water 1 & 3.725 & 564.45 & 255.00 & 0.708 & 55.84 & 261.87 \\
\hline Surface water 2 & 3.496 & 560.90 & 200.54 & 0.705 & 55.00 & 181.85 \\
\hline Surface water 3 & 3.309 & 514.75 & 168.00 & 0.705 & 54.00 & 173.85 \\
\hline YMWE, $^{[17]}$ & 1.000 & $4-10$ & - & - & - & - \\
\hline WHO, ${ }^{[15]}$ & 1.000 & $4-10$ & - & - & - & - \\
\hline Saudi Arabia standard ${ }^{[14]}$ & 1.000 & 100.00 & 600.00 & - & 10.00 & 5.00 \\
\hline Oman standard ${ }^{[12]}$ & 1.000 & 650.00 & 400.00 & - & 50.00 & 5.00 \\
\hline Jordanian standard ${ }^{[8]}$ & 1.500 & 350.00 & 350.00 & - & 45.00 & - \\
\hline
\end{tabular}

Table 6: Concentration of major anions and nitrogenous compounds

\begin{tabular}{lllllll}
\hline Parameter & $\mathrm{F}^{-}\left(\mathrm{mg}^{-1}\right)$ & $\mathrm{Cl}^{-}\left(\mathrm{mg}^{-1}\right)$ & $\mathrm{SO}_{4}^{-2}\left(\mathrm{mg}^{-1}\right)$ & $\mathrm{NO}_{2}^{-}\left(\mathrm{mg}^{-1}\right)$ & $\mathrm{NO}_{3}^{-}\left(\mathrm{mg}^{-1}\right)$ & $\left.\mathrm{NH}_{3}-\mathrm{N}^{-1} \mathrm{mg}^{-1}\right)$ \\
\hline BH1 & 0.442 & 110.00 & 19.683 & 0.029 & 14.17 & 0.031 \\
BH2 & 0.487 & 114.70 & 42.400 & 0.012 & 11.67 & 0.051 \\
BH3 & 0.510 & 313.47 & 117.700 & 0.022 & 11.83 & 0.134 \\
BH4 & 0.550 & 341.51 & 122.500 & 0.054 & 11.00 & 0.074 \\
BH5 & 0.720 & 281.10 & 101.750 & 1.684 & 5.83 & 2.554 \\
YMWE ${ }^{[17]}$ & 1.500 & 250.00 & 250.000 & 0.100 & 50.00 & 0.500 \\
WHO $^{[15]}$ & 1.500 & 250.00 & 250.000 & 0.100 & 50.00 & - \\
\hline
\end{tabular}

Major anions and nitrogenous compounds: These include Fluoride $\left(\mathrm{F}^{-}\right)$, Chloride $\left(\mathrm{Cl}^{-}\right)$, Sulfate $\left(\mathrm{SO}_{4}^{-2}\right)$, Nitrites $\left(\mathrm{NO}_{2}{ }^{-}\right)$, Nitrates $\left(\mathrm{NO}_{3}{ }^{-}\right)$and ammonia-N $\left(\mathrm{NH}_{3}^{-}\right.$ $\mathrm{N})$. The results are shown in Table 5 and 6.

The $\mathrm{F}^{-}$concentrations measured at the three sites of surface water are very close the values. The highest $\mathrm{F}^{-}$ concentration is reported at the upstream site with the value of $3.725 \mathrm{mg}^{-1}$, whereas the lowest $F^{-}$ concentration is reported at the downstream site with the value of $3.309 \mathrm{mg}^{-1}$. These results are grater than the standard acceptable levels of irrigation purpose determined by Yemen's Ministry of Water and Environment $^{[13,14,15]}$. These results compared to the Kuwait standard are very low. On the other hand these results are also high compared to the Saudi Arabia standard $^{[14]}$, Oman standard $^{[12]}$ and Jordanian standard $^{[8]}$. For the boreholes, the highest $F^{-}$ concentration is reported in BH5 with the value of 0.75 $\mathrm{mg}^{-1}$, whereas the lowest $\mathrm{F}^{-}$concentration is reported in BH1 with the value of $0.442 \mathrm{mg}^{-1}$. These results are high compared to the results obtained by Header et $a l^{[9]}$. These results, on other hand, are in agreement with the standard acceptable levels of drinking water determined by Yemen's Ministry of Water and Environment ${ }^{[13,14,15]}$.

The $\mathrm{Cl}^{-}$concentrations measured at the three sites of surface water are different. The highest $\mathrm{Cl}^{-}$ concentration is reported at the upstream site with the value of $564.45 \mathrm{mg}^{-1}$, whereas the lowest $\mathrm{Cl}^{-}$ concentration is reported at the downstream site with the value of $514.75 \mathrm{mg}^{-1}$. These results are higher than the results $\left(302 \mathrm{mg}^{-1}\right.$ ) obtained by Mohammed and Nakhla ${ }^{[11]}$. These results are lower than the Oman standard $^{[12]}$. On the contrary, these results are not within the standard acceptable levels of irrigation purpose determined by Yemen's Ministry of Water and Environment $^{[13,14,15]}$, Saudi Arabia standard ${ }^{[14]}$,
Jordanian standard ${ }^{[8]}$ and Kuwait standard (2001). According to $\mathrm{FAO}^{[7]}$, the $\mathrm{Cl}^{-}$concentration for surface irrigation is about $106.5 \mathrm{mg}^{-1}$ is considered slight to moderate. This indicates that, surface water is polluted and affected by the discharge of untreated wastewater directly to the valley. For the boreholes, the highest $\mathrm{Cl}^{-}$ concentration is reported in $\mathrm{BH} 4$ with the value of $341.51 \mathrm{mg}^{-1}$, whereas the lowest $\mathrm{Cl}^{-}$concentration is reported in $\mathrm{BH} 1$ with the value of $110 \mathrm{mg}^{-1}$.

The $\mathrm{Cl}^{-}$concentrations in $\mathrm{BH} 1$ and $\mathrm{BH} 2$ are lower than the results $\left(198.5 \mathrm{mg}^{-1}\right)$ obtained by Header et al. ${ }^{[9]}$, but the $\mathrm{Cl}^{-}$concentrations in $\mathrm{BH} 3, \mathrm{BH} 4$, and $\mathrm{BH} 5$ are high compared to the results obtained by Header $e t$ $a l .{ }^{[9]}$. The high $\mathrm{Cl}^{-}$concentrations in these boreholes can be attributed to migration of polluted surface water to the groundwater.

The concentrations of sulfate at the three surface water bodies are $255 \mathrm{mg}^{-1}, 200 \mathrm{mg}^{-1}$ and $168 \mathrm{mg}^{-1}$ respectively. The concentrations of $\mathrm{NO}_{3}{ }^{-}$at the three surface water bodies are $55.84 \mathrm{mg}^{-1}, 55 \mathrm{mg}^{-1}$ and 54 $\mathrm{mg}^{-1}$ respectively. These results are low values compared to Oman standard ${ }^{[12]}$, Saudi Arabia standard $^{[14]}$ and Jordanian standard ${ }^{[8]}$. For the boreholes, the highest concentration of $\mathrm{SO}_{4}$ is measured in $\mathrm{BH} 4$ with the value of $122.5 \mathrm{mg}^{-1}$, whereas the lowest concentration is measured in $\mathrm{BH} 1$ with the value of $19.68 \mathrm{mg}^{-1}$. The high concentrations of $\mathrm{SO}_{4}$ in $\mathrm{BH} 3$, $\mathrm{BH} 4$, and $\mathrm{BH} 5$ compared to the low concentrations of $\mathrm{SO}_{4}$ in $\mathrm{BH} 1$ and $\mathrm{BH} 2$ are due to the affected of these boreholes by polluted surface water. Although, the concentrations of $\mathrm{SO}_{4}$ in $\mathrm{BH} 3, \mathrm{BH} 4$ and $\mathrm{BH} 5$ are high, but did not pose any significant water quality problem, because these results are within the standard acceptable levels of drinking water determined by YMWE and $\mathrm{WHO}^{[13,14,15]}$. 


\section{Am. J. of Appl. Sci., 6 (4): 772-783, 2009}

The concentration of nitrogenous compounds indicates the occurrence of extensive anaerobic bacterial activities. Before the establishment of stringent regulations, sludges from wastewater treatment plants were most often spread on lands and buried in ditches as methods of disposal. As the sludge decays, nitrates are formed. Thus, in some situations, these methods of disposal have resulted in the nitrates percolating down the soil causing excessive contaminations of the groundwater. Nitrogen is a major component of wastewater. People eat meat and meat contains protein that, in turn, contains nitrogen. Nitrogen in protein is needed by humans in order to survive which, in turn, produces wastewater that must be treated ${ }^{[2]}$.

The concentrations of ammonia $\mathrm{NH}_{3}$ for the surface water bodies are different. The highest concentration is reported at the upstream site with the value of $261.87 \mathrm{mg}^{-1}$, whereas the lowest concentration is reported at the downstream site with the value of $173.85 \mathrm{mg}^{-1}$. Theses results are very high compared to the Saudi Arabia standard ${ }^{[14]}$, Oman standard ${ }^{12]}$. On the other hand, the concentrations of ammonia NH3 for the boreholes are different. The highest concentration is measured in BH5 with the value of $2.554 \mathrm{mg}^{-1}$, whereas, the lowest concentration is measured in $\mathrm{BH} 1$ with the value of $0.03 \mathrm{mg}^{-1}$. The high concentration of $\mathrm{NH} 3$ in BH5 is higher than the results obtained by Header et al. ${ }^{[9]}$ and higher than the standard acceptable levels of drinking water determined by YMWE ${ }^{1314,15]}$ and WHO. This means that, this borehole is the most affective boreholes by the polluted surface water.

Ammonia in wastewater is mixture of dissolved ammonia gas (NH3) and the ammonium ion (NH4+), often referred to as 'free' and 'saline' ammonia, respectively. Free ammonia at concentrations $>0.5 \mathrm{mg}$ $\mathrm{N} / 1$ is toxic to fish ${ }^{[6]}$.

According to Arcadio and Gregoria ${ }^{[2]}$ the free ammonia may hydrolyze producing the ammonium ion according to the following reaction:

$\mathrm{NH}_{3}+\mathrm{H}_{2} \mathrm{O} \quad \mathrm{NH}_{4}^{+}+\mathrm{OH}^{-}$

At $\mathrm{pH}$ levels below 7, the above equilibrium is shifted to the right and the predominant nitrogen species is $\mathrm{NH}_{4}{ }^{+}$, the ionized form. On the other hand, when the $\mathrm{pH}$ is above 7 , the equilibrium is shifted to the left and the predominant nitrogen species is ammonia.

The $\mathrm{NO}_{2}$ levels in groundwater are varied. The $\mathrm{mg} / \mathrm{l}$, whereas the lowest level is recorded in $\mathrm{BH} 2$ with the value of $0.012 \mathrm{mg} / \mathrm{l}$. The $\mathrm{NO}_{2}$ level in $\mathrm{BH} 5$ is close to the results obtained by Header et al. ${ }^{[9]}$. On the other hand, this value is high compared to the standard acceptable levels of drinking water determined by YMWE $^{[13,14,15]}$ and WHO. The reason may be due to the affect of this borehole by migration of polluted surface water to the groundwater.

The $\mathrm{NO}_{3}$ levels in the boreholes are very low and did not pose any significant water quality problem. Nitrate is reduced to nitrite in the stomach of infants, and nitrite is able to oxidize Haemoglobin $(\mathrm{Hb})$ to methaemoglobin (metHb), which is unable to transport oxygen around the body. Guideline value for combined nitrate plus nitrite should not exceed $1^{[13]}$. In this study the combined of nitrate plus nitrite did not exceed 1 . On the other hand, nitrite is oxidized into nitrate which can be quickly assimilated by plants or otherwise reduced again to nitrite and $\mathrm{NH}_{3}$.

Major cations: The major cations include $\mathrm{Fe}, \mathrm{Na}, \mathrm{K}$, $\mathrm{Ca}$, and $\mathrm{Mg}$. Among all the cations analysed, $\mathrm{Na}$ showed high concentration levels at three surface water bodies. The Fe concentrations are lower than the standard acceptable levels of irrigation purpose determined by Yemen's Ministry of Water and Environment ${ }^{[13,14,15]}$, WHO,Saudi Arabia standard, Jordanian standard $^{[8]}$ and Oman standard ${ }^{[12]}$. The Na concentrations are greater than the results $\left(227 \mathrm{mg}^{-1}\right)$ obtained by Mohammed and Nakhla ${ }^{[11]}$. The effect of sodium ions in irrigation water in reducing infiltration rate and soil permeability is dependent on the sodium ion concentration relative to the concentration of calcium and magnesium ions and the total salt concentration $^{[13]}$. On the other hand, these results are also high compared to YMWE ${ }^{[15,17]}$, WHO and Jordanian standards ${ }^{[8]}$. The Ca concentrations are high compared to the results obtained by Mohammed and Nakhla ${ }^{[11]}$.

On the contrary, these results are lower than the Jordanian standard ${ }^{[8]}$. The Mg concentrations are lower than Jordanian standard ${ }^{[8]}$ and Oman standard ${ }^{[12]}$.

The distribution of $\mathrm{Fe}, \mathrm{Na}$, and $\mathrm{K}$ in all boreholes did not pose any significant water quality problem, because these cations are within the standard acceptable levels of drinking water determined by $\mathrm{YMWE}^{[15,17]}$ and WHO. The presence of sodium in drinking water can affect persons suffering from heart, kidney, or circulatory ailments. It may elevate blood pressures of susceptible individuals. Sodium is plentiful in the highest level is recorded in BH5 with the value of 1.684 Table 7: Concentration of major cations

\begin{tabular}{llllll}
\hline Parameter & $\mathrm{Fe}\left(\mathrm{mg}^{-1}\right)$ & $\mathrm{Na}\left(\mathrm{mg}^{-1}\right)$ & $\mathrm{K}_{\left(\mathrm{mg}^{-1}\right)}$ & $\mathrm{Ca}\left(\mathrm{mg}^{-1}\right)$ & $\mathrm{Mg}\left(\mathrm{mg}^{-1}\right)$ \\
\hline Surface water 1 & 0.186 & 270 & 62.34 & 166.5 & 25.62 \\
Surface water 2 & 0.173 & 296 & 62.00 & 166.5 & 24.66
\end{tabular}


Surface water 3

YMWE, ${ }^{[17]}$

WHO, ${ }^{[15]}$

Saudi Arabia standard ${ }^{[14]}$

Oman standard ${ }^{[12]}$

Jordanian standard $^{[8]}$
Am. J. of Appl. Sci., 6 (4): 772-783, 2009

$\begin{array}{lllll}0.165 & 266 & 61.34 & 164.5 & 24.90 \\ 5.000 & 3-9 & - & - & - \\ 5.000 & 3-9 & - & - & - \\ 2.000 & - & - & - & - \\ 5.000 & - & - & - & 150.0 \\ 5.000 & 230.0 & - & 230.0 & 100.0\end{array}$

Table 8: Concentration of major cations and hardness

\begin{tabular}{|c|c|c|c|c|c|c|}
\hline Parameter & $\mathrm{Fe}\left(\mathrm{mg}^{-1}\right)$ & $\mathrm{Na}\left(\mathrm{mg}^{-1}\right)$ & $\mathrm{K}\left(\mathrm{mg}^{-1}\right)$ & $\mathrm{Ca}\left(\mathrm{mg}^{-1}\right)$ & $\operatorname{Mg}\left(\mathrm{mg}^{-1}\right)$ & Hardness $\left(\mathrm{mg}^{-1}\right)$ \\
\hline $\mathrm{BH} 1$ & 0.061 & 52.67 & 1.150 & 68.0 & 10.56 & 214 \\
\hline $\mathrm{BH} 2$ & 0.039 & 54.00 & 0.733 & 86.4 & 23.76 & 315 \\
\hline ВH3 & 0.065 & 101.00 & 2.920 & 219.6 & 33.64 & 690 \\
\hline $\mathrm{BH} 4$ & 0.016 & 94.70 & 3.320 & 257.0 & 43.68 & 700 \\
\hline BH5 & 0.057 & 82.67 & 4.850 & 180.0 & 39.60 & 615 \\
\hline YMWE $^{[17]}$ & 0.300 & 200.00 & - & 75.0 & 30.00 & 300 \\
\hline WHO, ${ }^{[15]}$ & 0.300 & 200.00 & - & 75.0 & 30.00 & 500 \\
\hline
\end{tabular}

common table salt that people use to flavor food to their $\operatorname{taste}^{[2]}$.

Among all the cations analysed, $\mathrm{Ca}$ showed high concentration levels in the boreholes. The highest content value is measured in $\mathrm{BH} 4$ with the value of 257 $\mathrm{mg} / \mathrm{l}$, whereas the lowest content value is measured in BH1 with the value of $68 \mathrm{mg}^{-1}$. the Ca contents in BH1 and $\mathrm{BH} 2$ are lower than the results obtained by Header et al. ${ }^{[9]}$. On the contrary, the Ca contents in $\mathrm{BH} 3, \mathrm{BH} 4$ and $\mathrm{BH} 5$ are greater than the results obtained by Header et al. ${ }^{[9]}$. The content values of $\mathrm{Mg}$ measured in the boreholes are varied. The highest content value is measured in BH4 with the value of $43.68 \mathrm{mg}^{-1}$, whereas the lowest content value is measured in $\mathrm{BH} 1$ with the value of $10.56 \mathrm{mg}^{-1}$. These results are low compared to the results obtained by Header et al. ${ }^{[9]}$. On the other hand, the $\mathrm{Ca}$ and $\mathrm{Mg}$ contents in $\mathrm{BH} 3, \mathrm{BH} 4$, and $\mathrm{BH} 5$ are not in agreements with the standard acceptable levels of drinking water determined by $\mathrm{YMWE}^{[14,15]}$ and $\mathrm{WHO}^{[15]}$. This means that, the affected of these boreholes by polluted surface water.

The high concentration of hardness is reported in BH4 with the value of $700 \mathrm{mg}^{-1}$ followed by BH3 with the value of $690 \mathrm{mg}^{-1}$, whereas the lowest concentration is reported in BH5 with the value of $615 \mathrm{mg}^{-1}$ Table 7. The concentration of hardness in $\mathrm{BH} 1$ and $\mathrm{BH} 2$ did not pose any water quality problems because the concentration of hardness are below the standard acceptable levels of drinking water determined by $\mathrm{YMWE}^{[17]}$ and $\mathrm{WHO}^{[15]}$. On the other hand, the high concentration of hardness in $\mathrm{BH} 3, \mathrm{BH} 4$ and $\mathrm{BH} 4$ are due to the affected of these boreholes by polluted surface water. Softening is the term given to the process of removing ions that interfere with the use of soap. These ions are called hardness ions due to the presence of multivalent cations, mostly calcium and magnesium. In the presence of hardness ions, however, soap does not form the lather immediately but reacts with the ions, preventing the formation of lather and forming scum. Lather will only form when all the hardness ions are consumed. This means that hard waters are hard to lather ${ }^{[2]}$.

There are two types of water hardness, temporary and permanent. Temporary hardness is removed when the water is boiled this is the process that leaves deposits of calcium carbonate on water heaters and kettles. Permanent hardness is formed as the cations pass over rocks containing sulphate ions ${ }^{[5]}$. This means that, water in $\mathrm{BH} 3, \mathrm{BH} 4$ and $\mathrm{BH} 5$ is very hard water. Table 7 shows the levels of hardness of water and the type of water.

Heavy metals: The heavy metals include lead $(\mathrm{Pb})$, Zinc (Zn), Nickel (Ni), Chromium (Cr), Cadmium (Cd) and Copper $(\mathrm{Cu})$. The concentrations of heavy metals are shown in Table 8 . The highest concentrations of heavy metals are recorded at the upstream site. $\mathrm{Zn}$ concentration is the highest concentration of heavy metals with the value of $3.735 \mathrm{mg}^{-1}$, whereas the lowest concentration of heavy metals is recorded for $\mathrm{Pb}$ with the value of $0.001 \mathrm{mg}^{-1}$, while the $\mathrm{Cd}$ and $\mathrm{Cr}$ are not detected.

The concentration of $\mathrm{Pb}$ and $\mathrm{Ni}$ are the highest at the upstream site, whereas the lowest concentration of $\mathrm{Pb}$ and $\mathrm{Ni}$ are in the downstream site. These results did not pose any water quality problems because these results are below the standard acceptable levels of irrigation purpose determined by Yemen's Ministry of

Table 9: Levels of hardness of water and the type of water

\begin{tabular}{ll}
\hline Water type & Equivalent \\
\hline Soft & $<50 \mathrm{mg} \mathrm{L}^{-1}$ as $\mathrm{CaCO}_{3}$ \\
Moderately hard & $50-150 \mathrm{mg} \mathrm{L}^{-1}$ as \\
$\mathrm{CaCO}_{3}$ & $150-300 \mathrm{mg} \mathrm{L}^{-1}$ as \\
$\mathrm{Hard}$ & \\
$\mathrm{CaCO}_{3}$ & $>300 \mathrm{mg} \mathrm{L}^{-1}$ as $^{\mathrm{CaCO}_{3}}$ \\
\hline
\end{tabular}


Am. J. of Appl. Sci., 6 (4): 772-783, 2009

Water and Environment ${ }^{[13,14,15]}$ WHO, Saudi Arabia standard $^{[14]}$, Jordanian standard ${ }^{[8]}$ and Oman standard $^{[12]}$.

$\mathrm{Zn}$ concentrations for three surface water sites are higher than the standard acceptable levels of irrigation purpose determined by Yemen's Ministry of Water and Environment $^{[13,14,15]}$, WHO and Saudi Arabia standard. On the contrary, these results are low compared to the Jordanian standard $^{[8]}$ and Oman standard ${ }^{[12]}$. This means that, the affective of surface water by fresh wastewater which directly discharge to the valley.

The highest concentration of $\mathrm{Cu}$ is recorded at the upstream site, whereas the lowest concentration is recorded at the downstream site. These results are high compared to the standard acceptable levels of irrigation purpose determined by Yemen's Ministry of Water and Environment $^{[13,14,15]}$, WHO, Saudi Arabia standard ${ }^{[14]}$, Jordanian standard $^{[8]}$ and Oman standard ${ }^{[12]}$. This means that, the affective of surface water by fresh wastewater which directly discharge to the valley.

For the boreholes the concentration of heavy metals are shown in Table $10 . \mathrm{Cu}$ concentration is the highest concentration of heavy metals with the value of
$2.75 \mathrm{mg}^{-1}$, whereas the lowest concentration of heavy metals is recorded for $\mathrm{Pb}$ with the value of $0.001 \mathrm{mg} / \mathrm{l}$, while the $\mathrm{Cd}$ and $\mathrm{Cr}$ are not detected (Table 9). The concentrations of $\mathrm{Pb}, \mathrm{Zn}$ and $\mathrm{Ni}$ did not pose any water quality problems because of the agreement of these results with standard acceptable levels of drinking water determined by $\mathrm{YMWE}^{[14,15]}$ and $\mathrm{WHO}^{[13]}$. The concentrations of $\mathrm{Cu}$ in all boreholes are different. The highest concentration of $\mathrm{Cu}$ is recorded in $\mathrm{BH} 4$ with the value of $2.75 \mathrm{mg}^{-1}$, whereas the lowest concentration of $\mathrm{Cu}$ is recorded in $\mathrm{BH} 1$ with the value of $0.11 \mathrm{mg}^{-1}$. The high concentration of $\mathrm{Cu}$ in $\mathrm{BH} 3, \mathrm{BH} 4$ and $\mathrm{BH} 5$ are close to the results obtained by Header et al. ${ }^{[9]}$. On the other hand, these results are not in agreement with standard acceptable levels of drinking water determined by $\mathrm{YMWE}^{[14,15]}$ and $\mathrm{WHO}^{[13]}$ and this means that these boreholes are affected by migration of polluted surface water to the groundwater. On the contrary, the concentration of $\mathrm{Cu}$ in $\mathrm{BH} 1$ and $\mathrm{BH} 2$ did not pose any water quality problems because the non affective of these two boreholes by polluted surface water.

Table 10: concentration of heavy metals at surface water bodies

\begin{tabular}{|c|c|c|c|c|c|c|}
\hline Parameter & $\mathrm{Pb}\left(\mathrm{mg}^{-1}\right)$ & $\mathrm{Zn}\left(\mathrm{mg}^{-1}\right)$ & $\mathrm{Ni}\left(\mathrm{mg}^{-1}\right)$ & $\mathrm{Cr}\left(\mathrm{mg}^{-1}\right)$ & $\mathrm{Cd}\left(\mathrm{mg}^{-1}\right)$ & $\mathrm{Cu}\left(\mathrm{mg}^{-1}\right)$ \\
\hline Surface water 1 & 0.007 & 3.735 & 0.013 & 0.00 & 0.00 & 2.634 \\
\hline Surface water 2 & 0.004 & 3.713 & 0.012 & 0.00 & 0.00 & 2.600 \\
\hline Surface water 3 & 0.001 & 3.671 & 0.011 & 0.00 & 0.00 & 2.576 \\
\hline $\mathrm{YMWE}^{[17]}$ & 5.0 & 2.000 & 0.500 & 0.10 & 0.01 & 0.200 \\
\hline $\mathrm{WHO}^{[15]}$ & 5.0 & 2.000 & 0.200 & 0.10 & 0.01 & 0.200 \\
\hline Saudi Arabia standard ${ }^{[14]}$ & 0.1 & 2.000 & 0.200 & 0.10 & 0.01 & 0.400 \\
\hline Oman standard ${ }^{[12]}$ & 0.1 & 5.000 & 0.100 & 0.05 & 0.01 & 0.050 \\
\hline Jordanian standard $^{[8]}$ & 0.2 & 5.000 & 0.200 & 0.02 & 0.01 & 0.200 \\
\hline
\end{tabular}

Table 11: concentration of heavy metals of groundwater

\begin{tabular}{llllll}
\hline Parameter & $\mathrm{Pb}\left(\mathrm{mg}^{-1}\right)$ & $\mathrm{Zn}\left(\mathrm{mg}^{-1}\right)$ & $\mathrm{Ni}\left(\mathrm{mg}^{-1}\right)$ & $\mathrm{Cr}\left(\mathrm{mg}^{-1}\right)$ & $\left.\mathrm{Cd}_{(\mathrm{mg}}^{-1}\right)$ \\
\hline BH1 & 0.000 & 0.157 & 0.001 & 0.00 & 0.000 \\
BH2 & 0.008 & 0.784 & 0.000 & 0.00 & 0.000 \\
BH3 & 0.005 & 0.494 & 0.0125 & 0.00 & 0.000 \\
BH4 & 0.003 & 0.259 & 0.0110 & 0.00 & 0.163 \\
BH5 & 0.001 & 0.316 & 0.0130 & 0.00 & 0.000 \\
YMWE $^{[17]}$ & 0.010 & 3.000 & 0.0200 & 0.05 & 0.000 \\
WHO $^{[15]}$ & 0.010 & 3.000 & 0.0200 & 0.05 & 0.003 \\
\hline
\end{tabular}

Bacteria: The results of microbiological analysis are shown in Table 11 and 12. The results show that BH1 and $\mathrm{BH} 2$ did not show any microorganism bacteria, whereas $\mathrm{BH} 3, \mathrm{BH} 4$ and $\mathrm{BH} 5$ show the presence of bacteria. Escherichia coli are the most widely adopted indicator of faecal pollution and they can also be isolated and identified fairly simply, with their numbers usually being given in the form of Faecal Coliforms (FC)/100 $\mathrm{mL}$ of wastewater. Escherichia coli are indicator organisms that are widely used to detect faecal contamination of water and the assumption is that if faecal coliform bacteria are present in a sample, then 
Am. J. of Appl. Sci., 6 (4): 772-783, 2009

Table 12: Microbiological results at Mitm valley

\begin{tabular}{llllr}
\hline Parameter & 3 of $10 \mathrm{~m}$ each & 3 of $1 \mathrm{~m}$ each & 3 of $0.1 \mathrm{~m}$ each & MPN Index per $100 \mathrm{~m}$ \\
\hline Surface water 1 & 3 & 3 & 3 & 2400 \\
Surface water 2 & 3 & 3 & 3 & 2400 \\
Surface water 3 & 3 & 3 & 3 & 2400 \\
BH1 & 0 & 0 & 0 & 0 \\
BH2 & 0 & 0 & 0 & 0 \\
BH3 & 3 & 3 & 2 & 1100 \\
BH4 & 3 & 3 & 2 & 1100 \\
BH5 & 3 & 3 & 2 & 1100 \\
APHA, 1998 & 3 & 3 & 3 & 2400 \\
\hline
\end{tabular}

human pathogenic bacteria could also exist Pathogenic organisms give rise to the greatest health concern in agricultural use of wastewaters, yet few epidemological studies have established definitive adverse health impacts attributable to the practice. Coliforms and Faecal Coliforms. The Coliform group of bacteria comprises mainly species of the genera Citrobacter, Enterobacter, Escherichia and Klebsiella and includes Faecal Coliforms, of which Escherichia coli is the predominant species ${ }^{[13]}$

The group belongs to the genera Escherichia, Aerobacter, Klebsiella and Paracolobacterium and mostly inhabits the intestinal tract of humans, although they could also be found in the outside environment. Although also found outside the intestinal tract, this group of organisms is used as an indicator for the presence of pathogens in waters. Surface waters can be used for drinking purposes after treatment, so effluents from sewage treatment plant discharges are limited for the acceptable concentrations of these organisms, thus the necessity for testing. ${ }^{[2]}$.

\section{CONCLUSIONS}

The upstream site of surface water is characterized by the highest concentration parameters. The results show the effect of surface water by fresh wastewater which directly discharges to the valley. The most parameters are not within the most standards which required for irrigation purpose. The results also show that three out of five boreholes are contaminated, where the concentration of physico-chemical parameters are above the standard acceptable levels which required for drinking water adapted by Yemen's Ministry of Water and Environment ${ }^{[14,15]}$ and $\mathrm{WHO}^{[13]}$ (2004). Boreholes 3,4 and 5 are contaminated by coliform group bacteria. Boreholes 1 and 2 did not pose any water quality problems and this means that theses boreholes are suitable for drinking water, whereas Boreholes 3, 4 and 5 are not suitable for drinking water. Therefore, urgency for wastewater treatment at this site is recommended to prevent further contamination to surface and groundwater.

\section{ACKNOWLEDGEMENTS}

All thanks are due to the Local Water Supply and Sanitation in Ibb city, and Yemen Standardization Metrology and Quality Control Organization for providing the research facilities throughout the study.

\section{REFERNCES}

1. Clesceri, L.S., A.E. Greenberg, A.D. Eaton, 1998. Standard Methods for the Examination of Water and Wastewater. 20th Edn., American Public Health Association, pp: 20. http://orton.catie.ac.cr/cgibin/wxis.exe/?IsisScript=BFHIA.xis\&method=post $\&$ formato $=2 \&$ cantidad $=1$ \&expresion $=m f n=009278$

2. Arcadio, P. and A. Gregoria, 2003. Physical and Chemical Treatment of Water and Wastewater. Sincero, A.P. and G.A. Sincero, (Eds.). UK.

3. Armon, R. and Y. Kott, 1994. The Health Dimesion of Groundwater Contamination. In: Groundwater Contamination and Control. Zoller, (Ed.). Marcl Dekker, Inc., New York.

4. Chae,Y.S., 2000. Groundwater and Aquifers. In: Groundwater and Surface Water Pollution. Liu, D.H. and B.G. Liptak, (Eds.). Boca Raton, Florida, America.

5. David, C., 2004. Small Water Supplies. Cromwell Press, Trowbridge, Wiltshire. India.

6. Duncan, M., 2003. Domestic Wastewater Treatment in Developing Countries. Duncan Mara. Cromwell Press, UK.

7. FAO. 1985. Food and Agriculture Organization, Water quality for agriculture, Irrigation and Drainage Paper 29 Rev., 1.

8. Jordanian, 2002. Treated Domestic Wastewater JS893:1995. Standards and Meteorology Corporation. Amman.

9. Header, A., M. Al Mashrake and E. Ibrahim, 2005. The Environmental Effect of reuse of wastewater for Irrigation. Ministry of Planning and International Corporation. Yemen, Sana'a. 
Am. J. of Appl. Sci., 6 (4): 772-783, 2009

10. Misra, S.G. and D. Mani, 1991. Soil Pollution. Efficient offset Printer ABC, New Delhi, India, pp: 6- 42.

11. Mohammed, S. and G. Nakhla, 1995. Wastewater reuse in Jubail, Saudi Arabia. Wat. Res., 29: 15791584.

12. Oman, 1993. Wastewater reuse and discharge. Ministry of Regional Municipilities and Enviroment.

13. Pescod, M.B., 1992. Wastewater Treatment and Use in Agriculture. Food and Agriculture Organization (FAO).

14. Saudi Arabia, 2000. Treated Wastewater and Reuse. Bylaw No. 42, 2000. Council of Ministers.

15. WHO., 2004. World Health Organisation. Guidelines for drinking water quality. Geneva.

16. YMWE, (1999). Yemen's Ministry of Water and Environment. Guidelines for drinking water quality. Sana'a, Republic of Yemen

17. YMWE, 1999. Yemen's Ministry of Water and Environment. Guidelines of treated of wastewater for irrigation. Sana'a, Republic of Yemen. 